\title{
A Case of Nasal Reconstruction of Fibrous Dysplasia Extensively Involving Middle Turbinate and Nasal Septum
}

\author{
Jung-Uk Han, Sang Hyok Suk, Jun Sick Im, and Ki Seung Kwon \\ Department of Otolaryngology, Maryknoll General Hospital, Busan, Korea \\ 중비갑개 및 비중격을 광범위하게 침범한 섬유성 이형성증 환자에서 비강 재건술 1예 \\ 한정욱 · 석상혁 · 임준식 · 권기승 \\ 메리놀병원 이비인후과
}

\author{
Received August 19, 2014 \\ Revised November 16, 2014 \\ Accepted November 19, 2014 \\ Address for correspondence \\ Jung-Uk Han, MD \\ Department of Otolaryngology, \\ Maryknoll General Hospital, \\ 121 Junggu-ro, Jung-gu, \\ Busan 600-730, Korea \\ Tel $+82-51-465-2205$ \\ Fax $+82-51-462-9419$ \\ E-mail hju0617@nate.com
}

\begin{abstract}
Fibrous dysplasia is a benign pathological condition of bone in which fibrous tissue gradually expands and replaces normal bone. Histologically, it shows various degrees of osseous metaplasia. Fibrous dysplasia frequently affects the maxilla, frontal bone, and mandible. The sign and symptoms of fibrous dysplasia of head and neck vary and are related to the location and extent of bony abnormalities. Facial asymmetry is the most common sign of fibrous dysplasia, while pain and ocular proptosis are the next most frequent symptoms. Fibrous dysplasia is rare in the nasal cavity, especially involving the turbinate and nasal septum. So we report a case of fibrous dysplasia, which extensively involves the middle turbinate and nasal septum, with a review of literature.

Korean J Otorhinolaryngol-Head Neck Surg 2015;58(7):497-502
\end{abstract}

\section{서 론}

섬유성 이형성증은 정상적인 골조직이 다양한 섬유조직과 미성숙한 골주로 서서히 대치되는 섬유골 조직의 양성 질환 이다.) 대개 소아기와 청소년기에 골증식이 시작하여 성인기 에 이르면 그 증식을 멈춘다고 알려져 있고 임상적으로 하나 의 골에 국한되는 단골형이 $70 \%$, 다수의 골 침범이 발생하 는 다골형이 $30 \%$ 를 차지한다. ${ }^{2,3)}$ 대부분의 섬유성 이형성증 은 특별한 증상이 없으면 경과 관찰하지만 안면비대칭이 있 거나 코막힘이 심할 때는 부분적 절제술(debulking surgery) 을 하기로 한다. 이비인후과 영역에서는 일반적으로 상악골, 전두골, 하악골 등의 안면골에 호발하나 중비갑개, 비중격, 경구개에 걸쳐서 매우 광범위하게 침범한 경우는 드물다. ${ }^{4-6)}$ 최근 저자들은 중비갑개 및 비중격을 광범위하게 침범한 섬 유성 이형성증으로 인해 수십 년간 코막힘이 있었던 환자에서 이과 수술용도의 cutting drill을 이용하여 비중격 교정술 및 중비갑개 부분 절제술로 비강 재건술을 시행하였기에 문헌고

찰과 함께 보고하는 바이다.

증 례

49세 남자가 수십 년 전부터 지속된 코막힘을 주소로 내원 하였다. 과거력상 유소년기에 교통사고 이후로 우측 안면부가 성장하는 형태를 보이다가 30대에 들어서 현재 상태와 비슷 하다고 하였으며 가족력상 특이 소견은 없었다(Fig. 1). 이학 적 검사상 내시경으로 양측 비강 접근이 거의 불가능하였고, 우측 중비갑개가 돌출되어 있었으며, 비중격이 좌측으로 심 하게 편위되어 있었으며, 구강 소견상 우측 경구개와 치은이 돌출되어 있었다(Fig. 2). 부비동 전산화단층촬영상 우측 중 비갑개 및 비중격은 경계가 균질환 골성 음영이, 우측 상악 동은 불균질한 골성 음영이 관찰되었으며 두개골 및 우측 경 구개에 걸친 광범위한 경화성의 불균질한 간유리 음영이 나 타났으나 부비동염 소견은 없었다(Fig. 3). 신경학적 검사상 특이 소견은 없었으며 혈액검사상 calcium과 alkaline phos- 

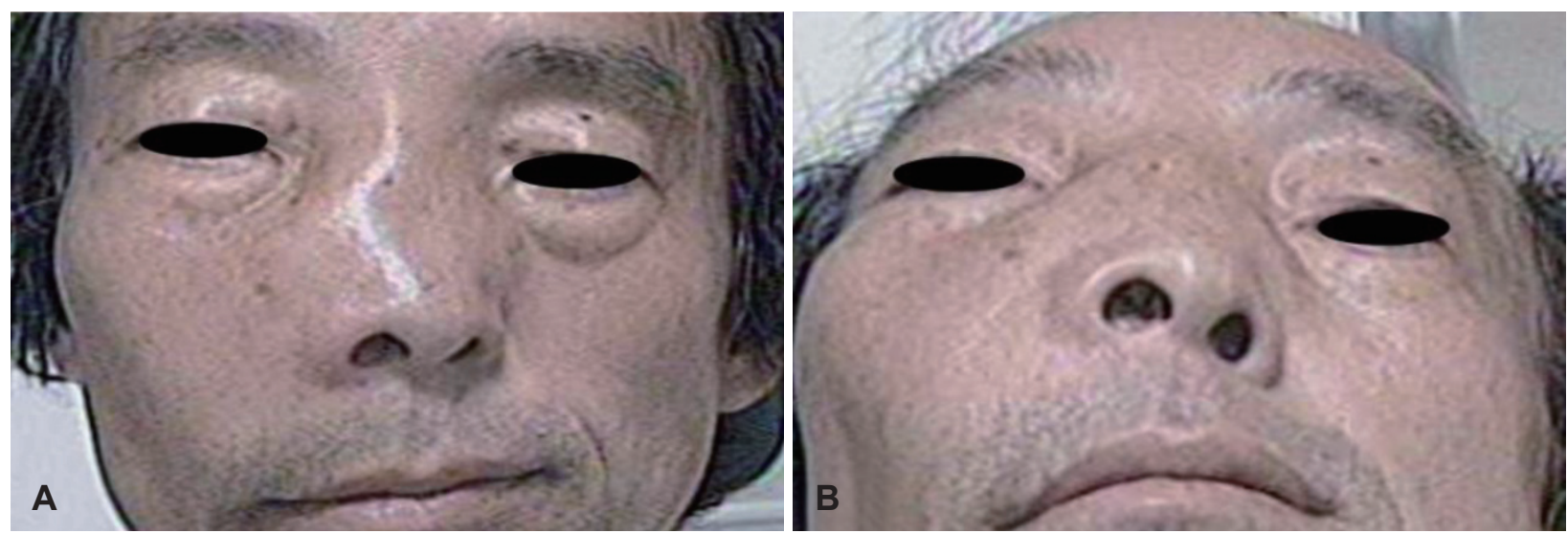

Fig. 1. Facial asymmetry are found on the external photograph. Frontal view (A). Basal view (B).
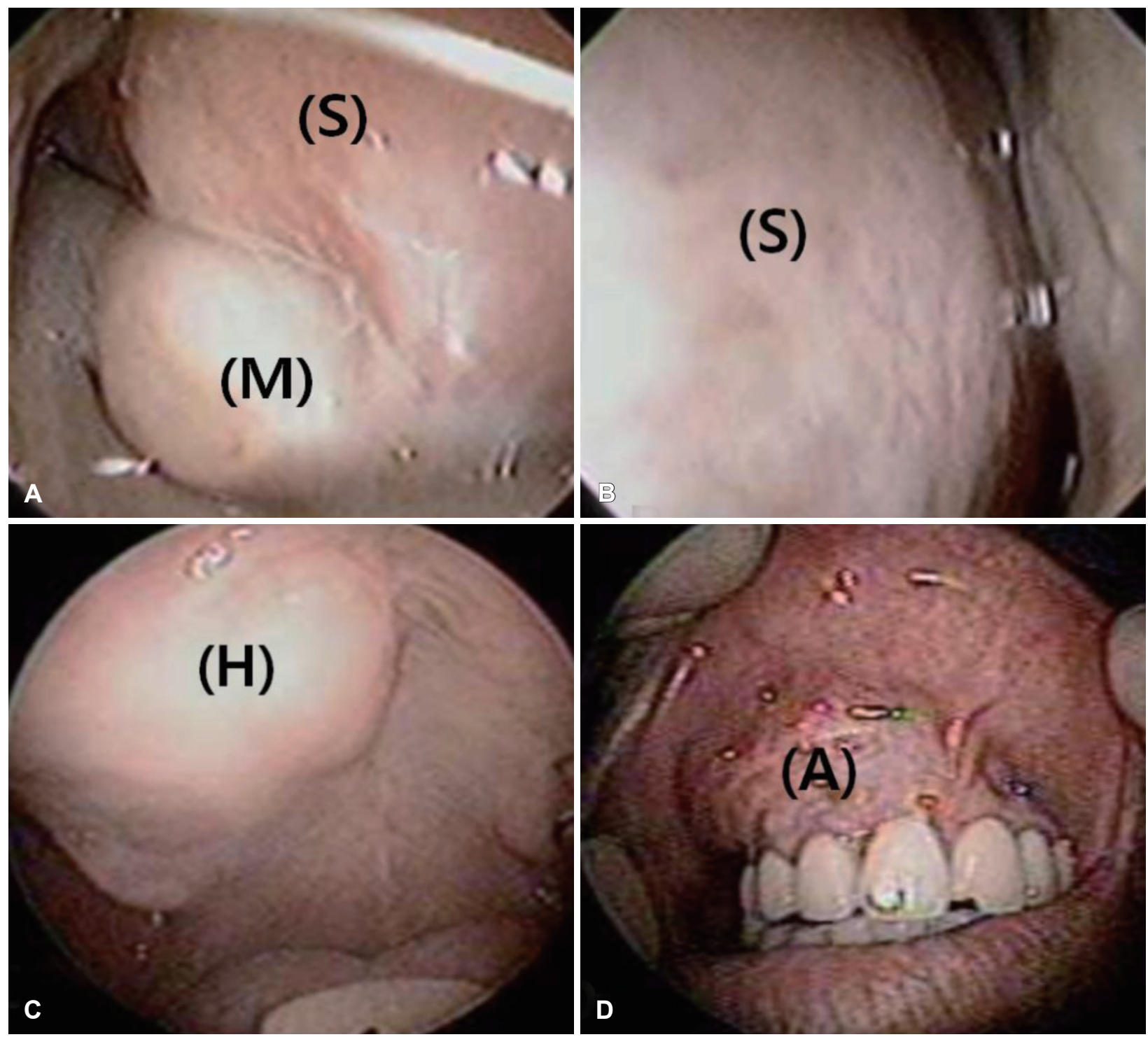

Fig. 2. Both (A: right, B: left) nasal cavities are nearly obstructed (M: middle turbinate, S: septum). Right hard palate (C) and alveolar process $(D)$ are protruded (H: hard palate, A: alveolar process). 
phatase도 정상 범위였다. 저자들은 섬유성 이형성증으로 진 단하였고, 코막힘 개선을 위해 비중격 교정술과 우측 중비갑 개 절제술을 시도하였다. 수술 중 중비갑개의 비대는 이과 수 술 용도의 드릴(6 mm cutting drill)을 이용하여 제거하였으며 빈코증후군(empty nose syndrome)의 발생을 막기 위해 중비 갑개 일부는 남겨 두었다. 처음에 우측 반관통절개(hemitransfixion incision)를 시도하였으나 비강확보가 힘들어 실패하 고 우측 중비갑개 부분 절제술을 먼저 시행하였다. 11번 blade
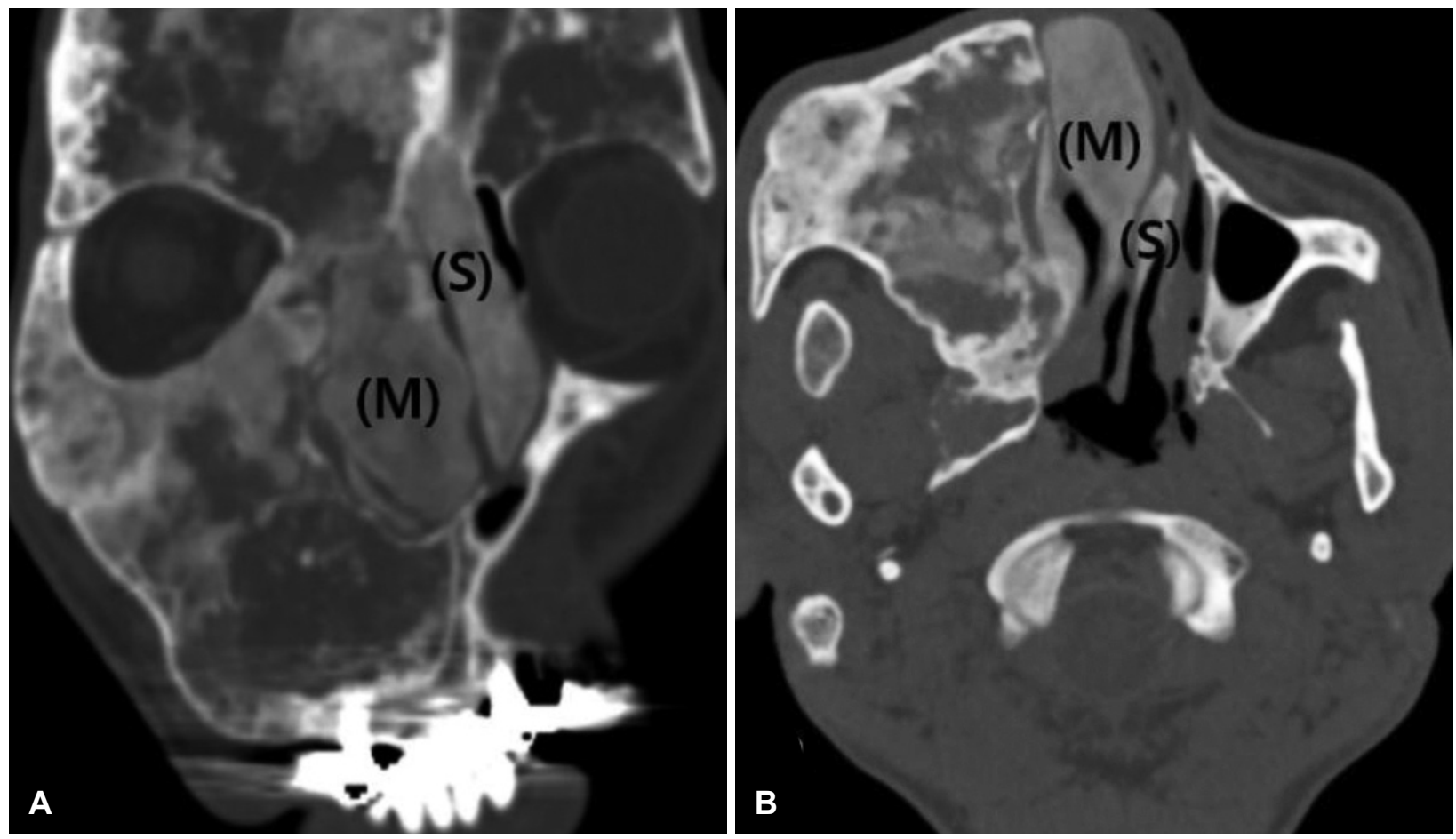

Fig. 3. Coronal (A) and axial (B) CT scan show ground glass appearance extended to bilateral frontal, right maxillary sinus, right middle turbinate, septum and right alveolar process (M: middle turbinate, S: septum).
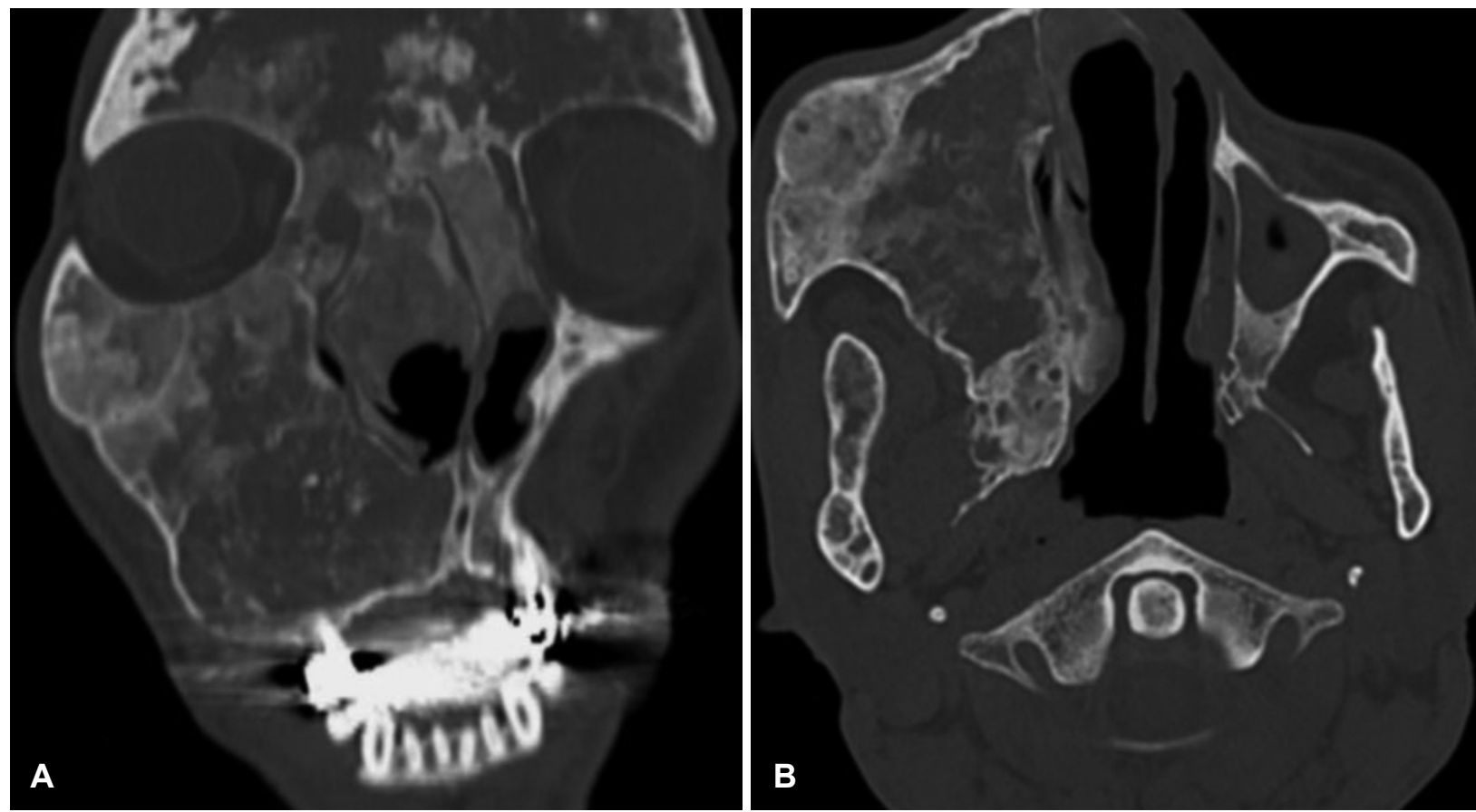

Fig. 4. On coronal CT scan, right middle turbinate and bony septum are partially removed (A). Both nasal cavities are relatively well built on axial CT scan (B). 
로 중비갑개 전방부에 절개를 가한 후 freer거상기로 중비갑개 의 골성 부분과 점막을 박리한 후 골성 부위를 Blakesley 절 단겸자로 제거하려고 했으나 실패하였고 일반적인 내시경 수 술용도의 겸자로는 절단이 불가능하여 이과 수술 용도의 6 mm cutting drill을 이용하여 중비갑개 전방 부위에 부분 절제 술을 시행하였으며 후방부에는 비중격 점막 및 이관입구 부위 인 Rosenmuller fossa 주위의 손상을 최소화하기 위해 $2 \mathrm{~mm}$ cutting drill을 이용하여 절제하였다. 우측 비강이 확보되어 우측 반관통절개(hemitransfixion incision)를 다시 시행하고 비중격 골부 및 연골 부위를 분리하고 연골 부분은 섬유성 이형성증이 침범한 소견이 없어서 $6 \mathrm{~mm}$ cutting drill로 비중 격의 골성 부위와 사골의 수직판 일부를 제거하였다. 이후 좌 측 비강이 충분히 관찰되어 실라스틱 판을 넣고 양측 Meroc$\mathrm{el}^{\circledR}$ (Medtronic Xomed, Jacksonville, FL, USA) 팩킹을 하고 수

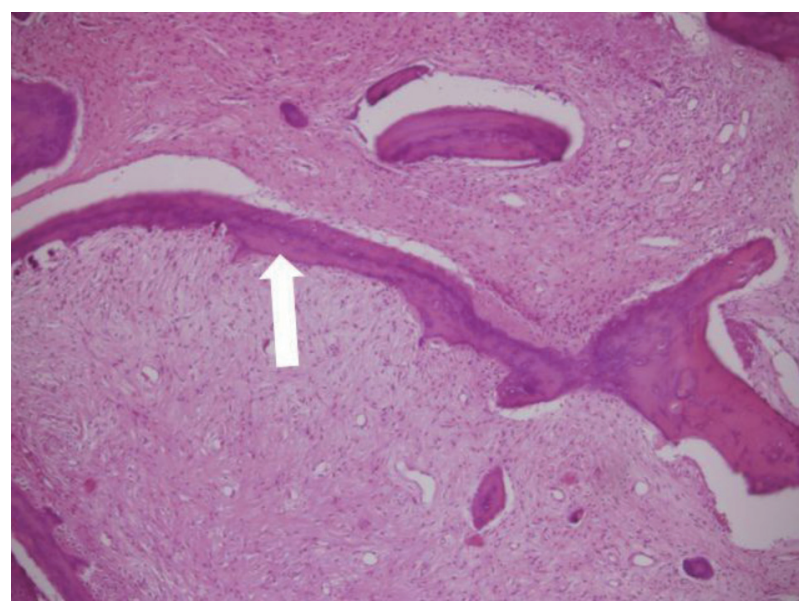

Fig. 5. Histologic finding shows woven bone (white arrow) with absence of osteoblastic rimming in loose fibrous stroma (H\&E stain, $\times 400)$.
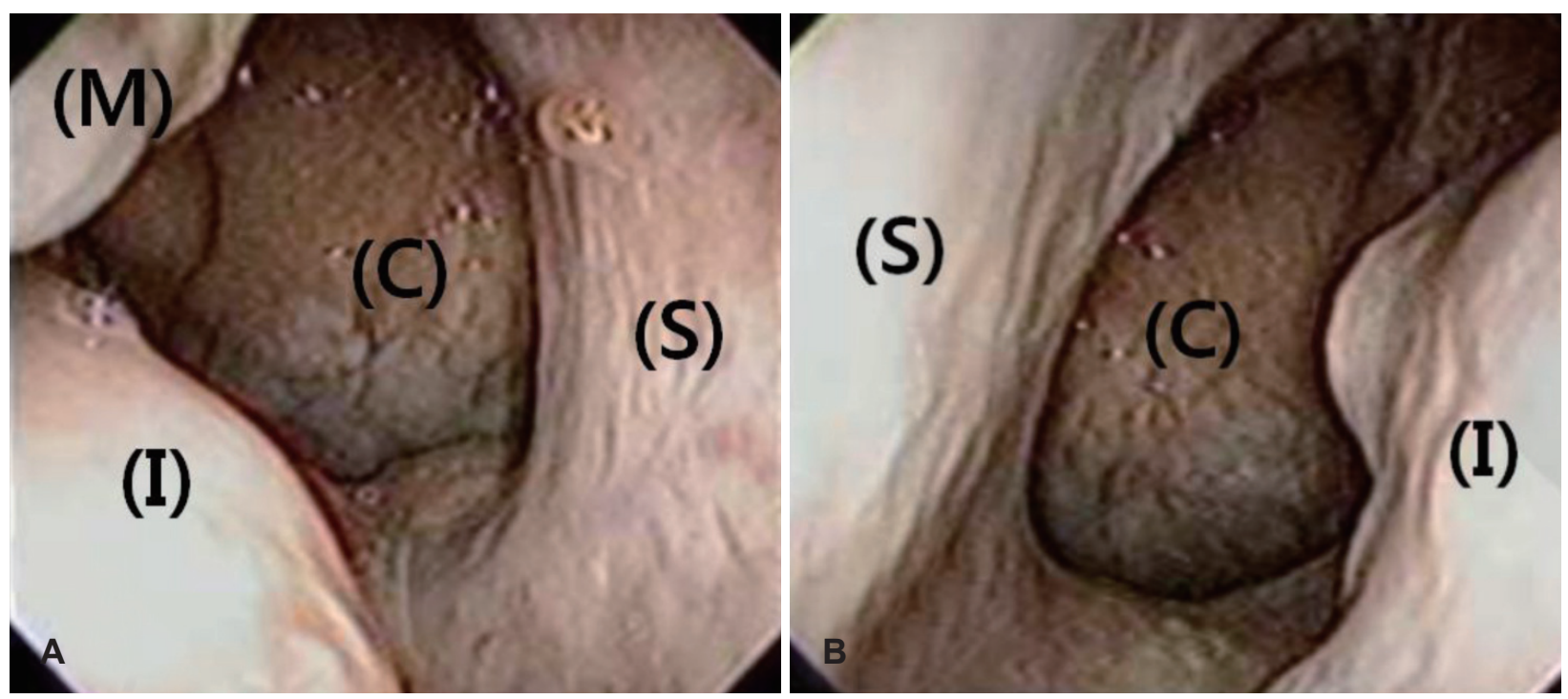

Fig. 6. Both (A: right, B: left) nasal cavities are well built (I: inferior turbinate, M: middle turbinate, S: septum, C: choana).
술을 마쳤다. 수술 후 4일째 Merocel ${ }^{\circledR}$ 팩킹을 제거하고 2주 일째 실라스틱 판을 제거한 후 양측 코막힘이 사라졌으며 술 후 시행한 부비동 전산화단층촬영에서 양측 비강에 충분한 공간이 관찰되었다(Fig. 4). 조직검사 결과 소용돌이 모양의 방 추상 세포들이 섬유 결합 조직을 이루고 석회화된 미성숙 골 주들이 불규칙적으로 산재해 있고, 골주 및 섬유 결합조직 사 이에 골아세포의 부재를 보이고 있어 섬유성 이형성증의 소견 과 일치하였다(Fig. 5). 수술 이후 7개월째 내시경상 후비공 (choana)까지 잘 관찰되고 있으며 후각저하 및 위축성 비염 등 의 합병증 없이 외래 추적 관찰 중이다(Fig. 6).

\section{고 찰}

섬유성 이형성증은 정상적인 해면골이 섬유조직과 불규칙 적인 골소주의 증식에 의하여 점진적으로 대치되는 양성 질환 으로 1938년 Lichtenstein ${ }^{7}$ 에 의하여 처음 명명되었고 1942년 Lichtenstein과 $\mathrm{Jaffe}^{8}$ 가 해면골내에 섬유 조직의 증식에 의해 발생하는 선천적 결함이라고 기술하였다.

원인은 잘 알려져 있지 않으나 선천성 및 유전적인 소인, 대 사성 장애, 골 외상 후 재생기능의 장애, 내분비 장애 등이 거 론되고 있으며 그 중에서 선천성 골이상 발육설이 가장 지지 를 받고 있다. ${ }^{9}$ 최근에는 유전자와 분자 생물학적으로 세포내 조절인자나 효소의 이상을 질병의 원인이라는 보고도 있다. ${ }^{10)}$ 본 증례의 경우 정확한 원인을 알 수 없지만 유소년기에 교통 사고 이후 안면부에 골성장이 발생한 것으로 보아 골 외상 후 재생기능의 장애를 원인으로 추론해 볼 수는 있다.

임상적으로 하나의 골을 침범하는 단골성, 둘 이상의 골을 침범하는 다골성, 성적 조숙이나 색소 침착 등의 골외 증상 
을 보이며 다발성 병변을 가진 파종형 또는 albright 증후군 으로 나눌 수 있다. ${ }^{3)}$ 가장 흔한 단골성은 대개 14 세 전후에서 발견되며 10 25\%에서 두개 안면골을 침범하며 늑골, 장골, 경골, 상악골, 하악골, 두개골, 상완골의 순서로 호발하며, 다 골성은 11세 전후에서 발견되며 50 100\%에서 두개 안면골 을 침범하는데 장골, 두개골, 경골, 상완골, 늑골, 비골, 요골, 척골, 하악골, 추골 등의 순서로 호발한다. McCune-Albright병이라고도 불리는 파종성은 약 3\% 정도로 매우 드물 며 다골성으로 침범할 뿐만 아니라 피부색소 병변(café-aulait spot), 성적 조숙 등의 내분비 기능 이상과 같은 골격계 이 외의 증상을 동반한다. ${ }^{11}$

임상 증상은 비특이적으로 대부분은 무증상이며 두개 안 면골에 발생한 경우에는 안면의 국소적 종창 같은 안면 비대 칭과 안구 돌출이 가장 흔하며 그 외 침범 부위에 따라 후각상 실, 비폐색, 비출혈 등이 있을 수 있으며 안구나 안구 주위 부 비동에 발생한 경우에 두통, 편위, 시력 상실, 복시 등이 나타 날 수 있다. ${ }^{3)}$ 본 증례의 경우 중비갑개 및 비중격에 걸쳐 광범 위하게 섬유성 이형성증이 침범하여 코막힘이 발생하였으나 후각장애는 없었다.

진단은 임상적, 방사선학적, 조직학적 소견을 종합하여 내 려야 하며 전산화단층촬영이 섬유성 이형성증의 진단 및 추 적 검사에 가장 좋은 영상 진단법이다. 방사선학 소견상 크 게 파젯병양성(혼합형), 경화성(치밀형), 낭성(용해형)으로 분 류할 수 있다. ${ }^{12}$ 파젯병양성은 전체 환자의 $56 \%$ 에서 나타나 며 투과성 및 비투과성 음영이 교대로 나타나고 광범위한 골 팽창을 보이며 상악골에서 가장 흔하게 나타난다. 간유리상 의 균질하게 증가된 음영을 보이는 경화성은 약 $23 \%$ 에서 나 타나며, 낭성은 약 $21 \%$ 에서 나타나고 명확한 경화성 경계를 갖는 투과성 병변을 보인다. ${ }^{12)}$

병리 소견은 육안적으로 겉은 회백색이나 노란색의 팽창된 딱딱한 껍질 모양의 피질골을 보이며 내부는 부드럽거나 견고 한 섬유조직으로 차 있다. 현미경적 소견은 섬유조직의 간질에 특징적인 한자 모양(Chinese letter)을 보이는 미성숙한 골주 (bony trabeculae)가 불규칙하게 배열되어 있으며 간질 조직에 서는 긴 방추상의 세포들이 소용돌이양 증식을 하는 것이 관 찰되며 특징적으로 골주에는 골아세포의 테두리가 없다. ${ }^{13)}$

감별할 질환으로 대표적으로 골화성 섬유종이 있는데 주 위와 경계가 명확한 골벽으로 둘러싸여 있으며, 전산화단층 촬영상 섬유성 이형성증에 비해 경계가 보다 명확하며 병리 소견에서 골주가 성숙한 층판골로 구성되어 있고 골아세포에 의하여 둘러싸여 있는게 특징적이다. 그 외 파제트병, 부갑상 선항진증, 불완전 골생성증과 같은 섬유성 질환들과 골종, 골 육종, 연골종 등과도 감별이 필요하다. ${ }^{14)}$
악성화 가능성은 매우 드물며, 전체의 $1 \%$ 에서 육종(sarco$\mathrm{ma}$ )으로 변화될 수 있으며 방사선 치료는 악성화 변화를 일으 킬 수 있다는 점에서 금기라 하겠다. ${ }^{12)}$

치료는 증식이 정지된 무증상의 작은 단일 국소 병변은 치 료할 필요가 없으며 안구돌출, 시력저하, 안면변형 등의 기능 상, 미용상 문제를 유발하는 경우, 심한 통증을 초래하는 경 우 등은 수술적 절제를 시행한다. 수술적 치료는 기능적, 미용 적으로 장애를 남기지 않는 한계 내에서 외과적 절제나 소파 술을 시행하는 것이 원칙이며, 본 증례처럼 상악골 및 경구개 까지 광범위하게 침범된 경우에는 미용적으로 구순하 안면 중앙 접근법을 이용하기도 한다. ${ }^{15,16)}$ 하지만 본 증례에서 환자 가 안면비대칭에 대해서 구순하 안면 중앙 접근법을 원하지 않았고 코막힘 개선만을 희망하여 비중격 교정수술 및 중비 갑개 부분 절제술을 시행하였다. 해외문헌에서도 본 증례처럼 중비갑개가 비대하여 코막힘 및 후각저하가 있는 환자에서 내 시경으로 중비갑개 부분 절제술을 시행한 후 후각저하 및 코 막힘이 완전히 회복된 예도 보고된 바 있다. ${ }^{14)}$

일반적으로 섬유성 이형성증 환자는 무증상일 때 경과 관 찰하는 것을 원칙으로 하지만 본 증례처럼 중비갑개, 비중격 을 광범위하게 침범하여 비강호흡이 힘들 정도의 심한 경우에 는 이과 수술용도의 drill을 이용하여 비중격 교정술 및 중비 갑개 부분 절제술을 시행하여 환자의 기능적 부분을 개선시 킬 수 있는 있기 때문에 부분적 절제술(debulking surgery)이 좋은 방법이 될 수 있다.

\section{REFERENCES}

1) Ozcan KM, Akdogan O, Gedikli Y, Ozcan I, Dere H, Unal T. Fibrous dysplasia of inferior turbinate, middle turbinate, and frontal sinus. B-ENT 2007;3(1):35-8.

2) Jan M, Dweik A, Destrieux C, Djebbari Y. Fronto-orbital sphenoidal fibrous dysplasia. Neurosurgery 1994;34(3):544-7; discussion 547.

3) Wu H, Yang L, Li S, Jin X, Xu J, Lu J, et al. Clinical characteristics of craniomaxillofacial fibrous dysplasia. J Craniomaxillofac Surg 2014; 42(7):1450-5.

4) Choi IS, Oh JC, Jun BH, Ahn BJ. A case of polyostotic fibrous dysplasia of the skull base paranasal sinus, inferior tubinate and septum. J Clin Otolaryngol Head Neck Surg 2002;13(2):220-4.

5) Park SY, Son WR, Han EM, Lee SH. A case of fibrous dysplasia involving the nasal septum. J Rhinol 2009;16(2):166-8.

6) Kim JM, Jun KH, Lee JH, Choi KH. A case of fibrous dysplasia confined bilateral middle turbinates. Korean J Otorhinolaryngol-Head Neck Surg 2014;57(7):481-3.

7) Lichtenstein L. Polyostotic fibrous dysplasia. Arch Surg 1938;36: 874-98.

8) Lichtenstein L, Jaffe HL. Fibrous dysplasia of bone. Arch Pathol 1942;33:777-816.

9) Cohen MM Jr, Howell RE. Etiology of fibrous dysplasia and McCuneAlbright syndrome. Int J Oral Maxillofac Surg 1999;28(5):366-71.

10) Candeliere GA, Glorieux FH, Prud'homme J, St-Arnaud R. Increased expression of the c-fos proto-oncogene in bone from patients with fibrous dysplasia. N Engl J Med 1995;332(23):1546-51.

11) Feldman MD, Rao VM, Lowry LD, Kelly M. Fibrous dysplasia of the 
paranasal sinuses. Otolaryngol Head Neck Surg 1986;95(2):222-5.

12) Shapeero LG, Vanel D, Ackerman LV, Terrier-Lacombe MJ, Housin D, Schwaab G, et al. Aggressive fibrous dysplasia of the maxillary sinus. Skeletal Radiol 1993;22(8):563-8.

13) Kim HJ, Shim SY, Lee CH, Chang C. Monostotic fibrous dysplasia of inferior turbinate. Korean J Otorhinolaryngol-Head Neck Surg 2010; 53(7):456-8.

14) Saetti R, Silvestrini M, Marino F, Narne S. Fibrous dysplasia of middle turbinate associated with Widal syndrome: endoscopic treatment of a rare case. Acta Otorhinolaryngol Ital 2004;24(5):288-91.

15) Frodel JL, Funk G, Boyle J, Richardson M. Management of aggressive midface and orbital fibrous dysplasia. Arch Facial Plast Surg 2000; 2(3):187-95.

16) Yang SJ, Choi JW, Chung YS, Ahn KM, Hong JP, Lee TJ, et al. Midfacial degloving approach for resectioning and reconstruction of extensive maxillary fibrous dysplasia. J Craniofac Surg 2012;23 (6):1658-61 